\title{
Effects of Intravenous Infusion of Conjugated Diene 18:3 Isomers on Milk Fat Synthesis in Lactating Dairy Cows
}

\author{
R. Gervais and P. Y. Chouinard ${ }^{1}$ \\ Département des Sciences Animales, Université Laval, Québec, Québec, Canada, G1V 0A6
}

\begin{abstract}
It has been previously established that trans-10, cis12 conjugated linoleic acid plays an important role in milk fat depression (MFD). However, in many situations of dietary induced MFD, the reduction in milk fat synthesis is much greater than what would be predicted based on the milk fat concentration of trans-10, cis-12 18:2. These observations suggest that other biohydrogenation intermediates could be implicated in MFD. The objective of this study was to evaluate the effects on milk fat synthesis of an intravenous administration of 2 conjugated diene 18:3 isomers (cis-9, trans-11, cis-15 and cis-9, trans-13, cis-15 18:3), which are intermediates in ruminal biohydrogenation of a-linolenic acid. Three multiparous Holstein dairy cows (days in milk $=189 \pm 37 \mathrm{~d}$; body weight $=640 \pm 69 \mathrm{~kg}$; mean \pm standard deviation), fitted with indwelling jugular catheters, were randomly assigned to a $3 \times 3$ Latin square design. For the first $5 \mathrm{~d}$ of each period, cows were infused intravenously with a $15 \%$ lipid emulsion providing 1) cis-9, trans-11, cis-15 18:3 + cis-9, trans-13, cis-15 18:3 + trans-10, cis-12 18:2 (CD18:3 + CLA); 2) cis-9, cis-12, cis-15 18:3+cis-9, cis-12 18:2 as a control (ALA + LA); or 3) cis-9, cis-12, cis-15 18:3 + trans-10, cis-12 18:2, as a positive control (ALA + CLA). Milk production was recorded, and milk was sampled daily at each milking for analyses of fat, protein, lactose, milk urea nitrogen, and somatic cell count. Dry matter intake, milk yield, and milk protein were not affected by treatment. Over the experimental period, milk fat content was decreased by $7 \%$ for cows that received either ALA + CLA or CD18:3 + CLA compared with ALA + LA. The temporal pattern of milk fat content showed a linear decrease during the infusion period for ALA + CLA and CD18:3 + CLA treatment groups. The transfer efficiencies of conjugated diene 18:3 isomers into milk fat averaged 39 and $32 \%$ for cis-9, trans-11, cis-15 18:3 and cis-9, trans-13, cis-15 18:3, respectively. The CD18:3 + CLA treatment had no effect on milk fat
\end{abstract}

Received April 4, 2008.

Accepted June 1, 2008.

${ }^{1}$ Corresponding author: Yvan.Chouinard@san.ulaval.ca concentration beyond that attributable to its trans-10, cis-12 18:2 content. In conclusion, results from the current study offered no support for a role of either cis-9, trans-11, cis-15 18:3 or cis-9, trans-13, cis-15 in MFD. Key words: conjugated diene 18:3, conjugated linolenic acid, milk fat depression, biohydrogenation

\section{INTRODUCTION}

Diet has a significant effect on milk fat synthesis in dairy cows. Supplementing highly fermentable carbohydrates or lipid supplements rich in polyunsaturated fatty acids such as plant or fish oils are known to decrease milk fat when fed to dairy cows (Davis and Brown, 1970; Sutton, 1989; Griinari et al., 1998). This phenomenon is referred to as milk fat depression (MFD). Several studies suggest that dietary induced MFD is due to changes in the rumen biohydrogenation process (NRC, 2001). Indeed, the biohydrogenation theory proposed by Bauman and Griinari (2001) stipulates that when a milk fat depressing diet is fed, the pathways of rumen biohydrogenation are altered, resulting in the production of unique fatty acid intermediates that are potent inhibitors of milk fat synthesis in the mammary gland. Trans-10, cis-12 18:2, one of many isomers of conjugated linoleic acid (CLA), has been identified as one such intermediate, and relation between the isomer and decreased milk fat output is well established (Baumgard et al., 2000). de Veth et al. (2004) combined results from 7 studies and established a curvilinear relationship between the increasing dose of trans-10, cis-12 18:2 infused into the abomasum and the reduction in milk fat production. However, in many situations of dietary induced MFD, the reduction in milk fat synthesis is much greater than what would be predicted based on the milk fat concentration of trans-10, cis-12 18:2 observed (Peterson et al., 2003; Piperova et al., 2004; Loor et al., 2005). These previous results suggested that there must be biohydrogenation intermediates other than trans-10, cis-12 18:2 implicated in MFD. Subsequent studies have provided evidence of a role for trans-9, cis-11 18:2 (Perfield et al., 2007) and cis-10, trans-12 18:2 (Sæbø et al., 2005b) in MFD. Milk fat content of many other bio- 
hydrogenation intermediates increases under dietary conditions of MFD (Shingfield and Griinari, 2007). Cis9, trans-11, cis-15 18:3 has been tentatively identified as the most common intermediate produced in the first step of the biohydrogenation process of a-linolenic acid (cis-9, cis-12, cis-15 18:3) by the action of the enzyme $\Delta^{12}$-cis, $\Delta^{11}$-trans isomerase in the rumen (Kepler and Tove, 1967). Subsequent studies also confirmed the presence, in small amounts, of cis-9, trans-13, cis-15 18:3 in milk (Destaillats et al., 2005b) and muscle (Plourde et al., 2007) lipid extracts from cattle, which can be considered as a second intermediate produced in the biohydrogenation process of a-linolenic acid. According to Banni (2002) and Sæbø et al. (2005a), these isomerised 18:3 (cis-9, trans-11, cis-15 18:3 and cis-9, trans-13, cis-15 18:3) can be referred to as conjugated diene 18:3 (CD18:3) isomers.

Different CD18:3 isomers have been previously studied for their effects on lipid metabolism (Koba et al., 2002; Destaillats et al., 2005a; Sæbø et al., 2005a; Plourde et al., 2006). Sæbø et al. (2005a) found no effect of an enrichment containing cis-6, trans-10, cis-12 18:3, a CD18:3 isomer produced by the $\Delta^{6}$-desaturation of dietary trans-10, cis-12 18:2. Koba et al. (2002) reported that compared with linoleic acid (cis-9, cis-12 18:2), CLA and, more potently, a mixture of conjugated diene and triene 18:3 isomers were found to decrease perirenal adipose tissue weight in rats. The same experiment demonstrated that conjugated 18:3, but not CLA, was found to increase serum and liver triacylglycerol, indicating that in rats, conjugated 18:3 modulates the body fat and triacylglycerol metabolism differently from CLA. The primary objective of the present study was to investigate the effect of intravenous infusion of an equal mixture of cis-9, trans-11, cis-15 18:3 and cis-9, trans-13, cis-15 18:3, two intermediates in the biohydrogenation of a-linolenic acid in the rumen, on milk fat synthesis in dairy cows.

\section{MATERIALS AND METHODS}

\section{Animals and Diets}

All procedures involving dairy cows were conducted according to the regulations of the Canadian Council on Animal Care and were approved by the Université Laval Animal Care Committee. Three multiparous Holstein cows (mean BW: $640 \pm 69 \mathrm{~kg}$ ) in midlactation (mean DIM: $189 \pm 37$ d) fitted with indwelling jugular catheters were intravenously infused with lipid emulsion enriched in 3 different mixtures of octadecatrienoic acid according to a $3 \times 3$ Latin square design. Experimental periods were $14 \mathrm{~d}$ in length. Animals were housed in a tie-stall facility. Throughout the experiment, cows were fed a TMR once daily (1000 h), which was formulated to meet or exceed the NRC requirements (NRC, 2001; Table 1). Orts were weighed daily just before feeding, and the amount of feed offered was adjusted to ensure $10 \%$ feed refusal. Feed samples were taken weekly, and DM content of silages was measured by oven-drying at $65^{\circ} \mathrm{C}$ for $48 \mathrm{~h}$. Proportions of TMR ingredients were adjusted weekly based on DM content of forages. Free access to water was provided at all time. Cows were weighed for 2 consecutive days at the beginning of each period.

\section{Infusion Procedures}

Three days before the infusion, 2 indwelling catheters were placed in each of the external jugular veins; one side was for infusion of lipid emulsion, and the contralateral side was for blood sampling. Catheters were kept patent with physiological saline plus either 200 $\mathrm{IU} / \mathrm{mL}$ of heparin between experimental days or $20 \mathrm{IU} /$ $\mathrm{mL}$ during the sampling period. Because pure CD18:3 supplements were not available, effects of these fatty acids were investigated using a supplement that contained $40 \%$ of an equal mixture of cis-9, trans-11, cis- 15 18:3 and cis-9, trans-13, cis-15 18:3 as well as $5.2 \%$ of trans-10, cis-12 18:2 (Naturia Inc., Sherbrooke, Québec, Canada; Table 2). The amount infused for the first treatment (CD18:3 + CLA) was calculated to provide $10 \mathrm{~g} / \mathrm{d}$ of CD18:3 and, as a consequence, supplied 1.3 g/d of trans-10, cis-12 18:2, a known potent inhibitor of milk fat synthesis. Therefore, as a positive control, another experimental fat mixture (ALA + CLA) was

Table 1. Composition of the TMR

\begin{tabular}{lc}
\hline Item & \% (DM basis) \\
\hline Ingredient & \\
Timothy silage & 32.1 \\
Corn silage & 26.1 \\
Soybean meal & 11.3 \\
Rolled barley & 21.2 \\
Cracked corn $_{\text {Mineral and vitamin premix }}{ }^{1}$ & 7.5 \\
Iodized salt $_{\text {Calcium carbonate }}$ & 0.8 \\
Chemical & 0.3 \\
DM, \% as fed & 0.7 \\
CP & \\
NDF & 47.9 \\
ADF & 16.2 \\
Ca & 38.6 \\
P & 20.0 \\
NE & Mcal/kg \\
\hline
\end{tabular}

${ }^{1}$ Contained $15 \% \mathrm{Ca}, 5 \% \mathrm{P}, 5 \% \mathrm{Mg}, 25 \% \mathrm{NaCl}, 40 \mathrm{mg} / \mathrm{kg}$ of $\mathrm{Co}, 3,500$ $\mathrm{mg} / \mathrm{kg}$ of Fe, $100 \mathrm{mg} / \mathrm{kg}$ of I, $850 \mathrm{mg} / \mathrm{kg}$ of Cu, 3,100 mg/kg of Mn, 30 $\mathrm{mg} / \mathrm{kg}$ of Se, 3,400 mg/kg of Zn, $350 \mathrm{kIU} / \mathrm{kg}$ of vitamin A, $150 \mathrm{kIU} / \mathrm{kg}$ of vitamin $\mathrm{D}$, and $2,000 \mathrm{IU} / \mathrm{kg}$ of vitamin $\mathrm{E}$.

${ }^{2}$ Calculated from ingredient components using the average for intake and cow characteristics (NRC, 2001). 
Table 2. Fatty acid composition of lipid supplements and amounts infused daily in each treatment group

\begin{tabular}{|c|c|c|c|c|c|}
\hline Variable & $\begin{array}{l}\text { Oleic } \\
\text { acid }^{1}\end{array}$ & $\begin{array}{l}\text { Linoleic } \\
\text { acid }^{2}\end{array}$ & $\begin{array}{l}\text { Linolenic } \\
\text { acid }^{3}\end{array}$ & $\begin{array}{c}\text { Conjugated } \\
\text { linoleic acid }\end{array}$ & $\begin{array}{l}\text { Conjugated } \\
\text { diene } 18: 3^{5}\end{array}$ \\
\hline \multicolumn{6}{|l|}{ Fatty acid, $\%$ by weight } \\
\hline $14: 0$ & 2.93 & 0.10 & $<0.01$ & 0.05 & $<0.01$ \\
\hline cis-9 16:1 & 4.20 & 0.13 & $<0.01$ & 0.07 & 0.07 \\
\hline $18: 0$ & 0.87 & 4.08 & $<0.01$ & 2.31 & 0.14 \\
\hline cis-9 18:1 & 61.08 & 15.40 & 0.64 & 11.08 & 17.49 \\
\hline cis-9, trans-11 18:2 & 0.07 & 0.08 & $<0.01$ & 37.85 & 4.25 \\
\hline trans -10, cis-12 18:2 & 0.07 & 0.02 & $<0.01$ & 38.43 & 5.24 \\
\hline cis-9, trans-11, cis-15 18:3 & $<0.01$ & $<0.01$ & $<0.01$ & $<0.01$ & 20.34 \\
\hline cis-9, trans-13, cis-15 18:3 & $<0.01$ & $<0.01$ & $<0.01$ & $<0.01$ & 20.34 \\
\hline Others & $15.15^{6}$ & $3.64^{7}$ & $0.27^{8}$ & $3.41^{9}$ & $6.73^{10}$ \\
\hline \multicolumn{6}{|l|}{ Treatment } \\
\hline
\end{tabular}

${ }^{1}$ VWR International, Ville Mont-Royal, Québec, Canada.

${ }^{2}$ Sigma-Aldrich Canada Ltd., Oakville, Ontario, Canada.

${ }^{3}$ Larodan Fine Chemicals, Malmö, Sweden.

${ }^{4}$ Clarinol A-80; Loders Croklaan, Channahon, IL.

${ }^{5}$ Conjugated diene 18:3; Naturia, Sherbrooke, Québec, Canada.

${ }^{6}$ Mainly other 18:1 isomers.

${ }^{7}$ Mainly other 18:2 isomers (nonconjugated) and other 18:1 isomers.

${ }^{8}$ Mainly Y-linolenic acid.

${ }^{9}$ Mainly other CLA isomers and 20:0.

${ }^{10}$ Mainly unknown and other isomers of 18:1, 18:2, and 18:3.

used, containing the same amount of trans-10, cis-12 18:2 (Clarinol A-80; Loders Croklaan, Channahon, IL), and in which CD18:3 was replaced with a-linolenic acid. Treatments also included a control (ALA + LA), in which CD18:3 and trans-10, cis-12 18:2 were replaced with a-linolenic acid and linoleic acid, respectively. Free fatty acid supplements (oleic acid, cis-9 18:1: VWR International, Ville Mont-Royal, Québec, Canada; linoleic acid: Sigma-Aldrich Canada Ltd., Oakville, Ontario, Canada; a-linolenic acid; Larodan Fine Chemicals, Malmö, Sweden) were included in experimental infusates to equilibrate the amounts of total 18:1, 18:2, and 18:3 among treatments (Table 3).

The experimental free fatty acid mixtures were diluted in $215 \mathrm{~g}$ of $20 \%$ Intralipid (Baxter Corporation, Toronto, Ontario, Canada), to which was added $2 \mathrm{~g}$ of phosphatidylcholine (Sigma-Aldrich Canada Ltd.) and $13 \mathrm{~g}$ of glycerine (Fisher Scientific Company, Ottawa, Ontario, Canada) as emulsifiers and brought to $450 \mathrm{~mL}$ with sterile water. Emulsions were obtained using a high-pressure homogenizer (Emulsi-flex-C50; Avestin Inc., Ottawa, Ontario, Canada), sterilized at $121^{\circ} \mathrm{C}$ for 20 min (MLS-3020U, Sanyo Electric Co. Ltd., Bensenville, IL) and subsequently cooled to $4^{\circ} \mathrm{C}$ until used.
All treatments were intravenously infused for $5 \mathrm{~d}$ with a 9-d interval between periods. Lipid emulsions were continuously infused by pumps (Plum Lifecare Pumps, series 1.6; Abbott Laboratories, Chicago, IL) so that daily infusion volume $(450 \mathrm{~mL})$ was delivered over a 24-h period.

\section{Sampling, Measurements, and Analyses}

Cows were milked twice daily at 0700 and $1700 \mathrm{~h}$. Milk was sampled, and milk yield was recorded using calibrated milk meters (Flomaster Pro, DeLaval, Tumba, Sweden) at each milking. Milk samples were kept at $4^{\circ} \mathrm{C}$ using bronopol as a preservative, before analysis for fat, protein, lactose, MUN, and SCC using a Foss Milkoscan 4000 (Foss Electric, Hillerød, Denmark) combined with a Bentley 2000 (Bentley Instruments, Chaska, MN). All milk composition analysis was conducted at the Québec Dairy Production Centre of Expertise (Ste-Anne-de-Bellevue, Québec, Canada). Additional milk samples were collected and stored at $-20^{\circ} \mathrm{C}$ without preservative for subsequent analysis.

Lipid extraction of milk samples was performed, and the extracted lipids were methylated according to 
Table 3. Fatty acids provided on a daily basis during intravenous infusion

\begin{tabular}{|c|c|c|c|}
\hline \multirow[b]{2}{*}{ Fatty acid, g/d } & \multicolumn{3}{|c|}{ Treatment } \\
\hline & $\mathrm{ALA}+\mathrm{LA}$ & $\mathrm{ALA}+\mathrm{CLA}$ & CD18:3 + CLA \\
\hline \multicolumn{4}{|l|}{$\overline{\text { Free fatty acid }}{ }^{1}$} \\
\hline \multicolumn{4}{|l|}{$18: 1$} \\
\hline cis -9 & 4.0 & 4.0 & 4.0 \\
\hline \multicolumn{4}{|l|}{$18: 2$} \\
\hline cis -9, cis -12 & 5.8 & 3.3 & 3.5 \\
\hline cis -9, trans -11 & 0.0 & 1.2 & 1.0 \\
\hline trans -10, cis -12 & 0.0 & 1.3 & 1.3 \\
\hline Total & 5.8 & 5.8 & 5.8 \\
\hline \multicolumn{4}{|l|}{$18: 3$} \\
\hline cis -9, cis -12, cis -15 & 12.2 & 12.2 & 2.2 \\
\hline cis- 9, trans -11, cis -15 & 0.0 & 0.0 & 5.0 \\
\hline cis -9, trans -13, cis -15 & 0.0 & 0.0 & 5.0 \\
\hline Total & 12.2 & 12.2 & 12.2 \\
\hline Others & 2.4 & 2.2 & 2.6 \\
\hline \multicolumn{4}{|l|}{ Esterified fatty acids ${ }^{2}$} \\
\hline $16: 0$ & 23.0 & 23.1 & 22.9 \\
\hline cis-9 18:1 & 42.4 & 42.5 & 42.2 \\
\hline cis-9, cis-12 18:2 & 102.8 & 103.1 & 102.4 \\
\hline cis- 9, cis-12, cis-15 18:3 & 11.0 & 10.2 & 10.9 \\
\hline Others & 28.5 & 28.6 & 28.4 \\
\hline
\end{tabular}

Chouinard et al. (1997). Composition analyses of the fatty acids were carried out with a gas chromatograph (HP 5890A Series II, Hewlett-Packard, Palo Alto, CA) equipped with a $100-\mathrm{m}$ CP-Sil 88 capillary column (i.d., $0.25 \mu \mathrm{m}$; film thickness, $0.20 \mu \mathrm{m}$; Chrompack, Middleburg, the Netherlands) and a flame ionization detector. Two oven temperature programs were used in this study. To screen milk fatty acid composition, a first temperature program was as follows: at the time of sample injection, the column temperature was $80^{\circ} \mathrm{C}$ for $1 \mathrm{~min}$, then ramped at $2^{\circ} \mathrm{C} / \mathrm{min}$ to $215^{\circ} \mathrm{C}$ and maintained for $30 \mathrm{~min}$. A second temperature program was used to separate the 2 CD18:3 isomers: at the time of sample injection, the column temperature was $120^{\circ} \mathrm{C}$ for $180 \mathrm{~min}$, then increased at $10^{\circ} \mathrm{C} / \mathrm{min}$ to $220^{\circ} \mathrm{C}$ and maintained isothermal for $20 \mathrm{~min}$ (Plourde et al., 2007). For both programs, inlet and detector temperatures were 220 and $230^{\circ} \mathrm{C}$, respectively. The split ratio was 100:1. The flow rate for hydrogen carrier gas was $1 \mathrm{~mL} / \mathrm{min}$. Most fatty acid peaks were identified and quantified using either a quantitative mixture or pure methyl ester standards (Larodan Fine Chemicals; Sigma-Aldrich Canada Ltd.; Matreya LLC, Pleasant Gap, PA; Nu-Chek Prep, Elysian, MN). The CD18:3 isomers were identified using a qualitative standard obtained from Naturia Inc. Because no quantitative standard was available, the peak response factor for cis-9, cis-12, cis-15 18:3 was used to adjust the peak areas of the CD18:3 isomers. Standards for trans-5 18:1, trans-10 18:1, trans-15 18:1, trans-16 18:1, and cis-15 18:1 were not available commercially and were identified by order of elution according to Precht et al. (2001). The response factor for cis-9 18:1 was used to quantify these other $18: 1$ isomers.

Blood was collected on $\mathrm{d} 4$ and 5 of infusion twice daily $(0800$ and $1700 \mathrm{~h})$. Blood samples were withdrawn via the jugular catheter and transferred into Vacutainer tubes that contained no preservative (Vacutainer 366430, Becton Dickinson, Franklin Lakes, NJ) to determine serum glucose, triacylglycerol, and NEFA concentrations. Blood samples were allowed to clot at room temperature $\left(20^{\circ} \mathrm{C}\right)$ for approximately 3 $\mathrm{h}$ and were centrifuged at $956 \times \mathrm{g}$ for $15 \mathrm{~min}$ at $4^{\circ} \mathrm{C}$. The supernatants were transferred to microtubes and frozen at $-20^{\circ} \mathrm{C}$ for later analysis. Frozen serum was submitted to the Faculté de Médecine Vétérinaire, Université de Montréal (St-Hyacinthe, Québec, Canada) for the measurement of serum NEFA (FA 115 kit; Randox Laboratories Ltd., Crumlin, UK) and glucose (reagent 442640; Beckman Coulter Inc., Mississauga, Ontario, Canada) using an automated autoanalyzer (Synchron CX5 Clinical System; Beckman Coulter Inc., Fullerton, CA). Blood triacylglycerol was measured using a commercial kit (Sigma-Aldrich Canada Ltd.). 


\section{Statistical Analysis}

Data were analyzed as a $3 \times 3$ Latin square design using the PROC MIXED procedure of SAS (SAS Institute, Cary, NC) according to the model:

$$
\mathrm{Y}_{\mathrm{ijk}}=\mu+\mathrm{T}_{\mathrm{i}}+\mathrm{P}_{\mathrm{j}}+\mathrm{C}_{\mathrm{k}}+\varepsilon_{\mathrm{ijk}}
$$

where $\mathrm{Y}_{\mathrm{ijk}}=$ individual observation; $\mu$ = overall mean; $\mathrm{T}_{\mathrm{i}}=$ effect of treatment $(\mathrm{i}=1,2$, and 3$) ; \mathrm{P}_{\mathrm{j}}=$ effect of period $(\mathrm{j}=1,2$, and 3$) ; \mathrm{C}_{\mathrm{k}}=$ effect of cow $(\mathrm{k}=1,2$, and 3 ; treated as a random effect); and $\varepsilon_{\mathrm{ijk}}=$ residual error term.

Period was repeated with the subject being cow. In the event that treatment effects were established, multiple comparisons were performed using the TukeyKramer adjustment (SAS Institute).

To study the temporal pattern of milk fat content and selected milk fatty acids during intravenous infusion of fatty acid supplements, data were analyzed as repeated measures within the Latin square using a mixed model:

$$
\mathrm{Y}_{\mathrm{ijkl}}=\mu+\mathrm{T}_{\mathrm{i}}+\mathrm{P}_{\mathrm{j}}+\mathrm{C}_{\mathrm{k}}+\mathrm{D}_{\mathrm{l}}+(\mathrm{T} \times \mathrm{D})_{\mathrm{il}}+\varepsilon_{\mathrm{ijkl}} \text {, }
$$

where $\mathrm{D}_{1}=$ effect of day of infusion $(\mathrm{l}=0$ to 5$)$ and $(\mathrm{T} \times$ $\mathrm{D})_{\mathrm{il}}=$ effect of the interaction between treatment and day of infusion.

The subject of the repeated statement was the cow $\times$ period interaction. When an effect of day of infusion or a treatment $\times$ day of infusion interaction were detected, linear and quadratic contrasts for time effect were performed.
The latter statistical model with effect of day of infusion replaced by effect of sampling time $(l=0800$ or $1700 \mathrm{~h}$ ) was used to analyze serum glucose, NEFA, and triacylglycerol. Because there was no sampling time $\times$ treatment interaction, mean concentrations of serum glucose, NEFA, and triacylglycerol sampled at 0800 and $1700 \mathrm{~h}$ on $\mathrm{d} 4$ and 5 were combined for statistical analysis according to the first model described previously.

Significance was declared at $P<0.05$, and trends were declared at $P<0.10$. The values reported are least squares means and standard errors.

\section{RESULTS AND DISCUSSION}

Many studies have demonstrated that trans-10, cis-12 18:2 plays a major role in MFD (Baumgard et al., 2000, 2001). Results from these previous trials led to the establishment of a curvilinear relationship between milk fat percentage and milk fat concentration of trans-10, cis-12 18:2 (Peterson et al., 2002; de Veth et al., 2004). However, in many situations of MFD, the magnitude of decrease in milk fat synthesis is much greater than the expected reduction based on the milk fat concentration of trans-10, cis-12 18:2 (Perfield et al., 2002; Peterson et al., 2003; Gervais et al., 2005). This suggests that other intermediates in the biohydrogenation of polyunsaturated fatty acids in the rumen could act as potent inhibitors of milk fat synthesis.

In the current study, a fatty acid supplement was provided to lactating dairy cows in an effort to study the effect on milk fat synthesis of isomers of CD18:3, intermediates produced during metabolism of a-linolenic

Table 4. Dry matter intake, milk yield, and milk composition from lactating cows during intravenous infusion of fatty acid supplements ${ }^{1}$

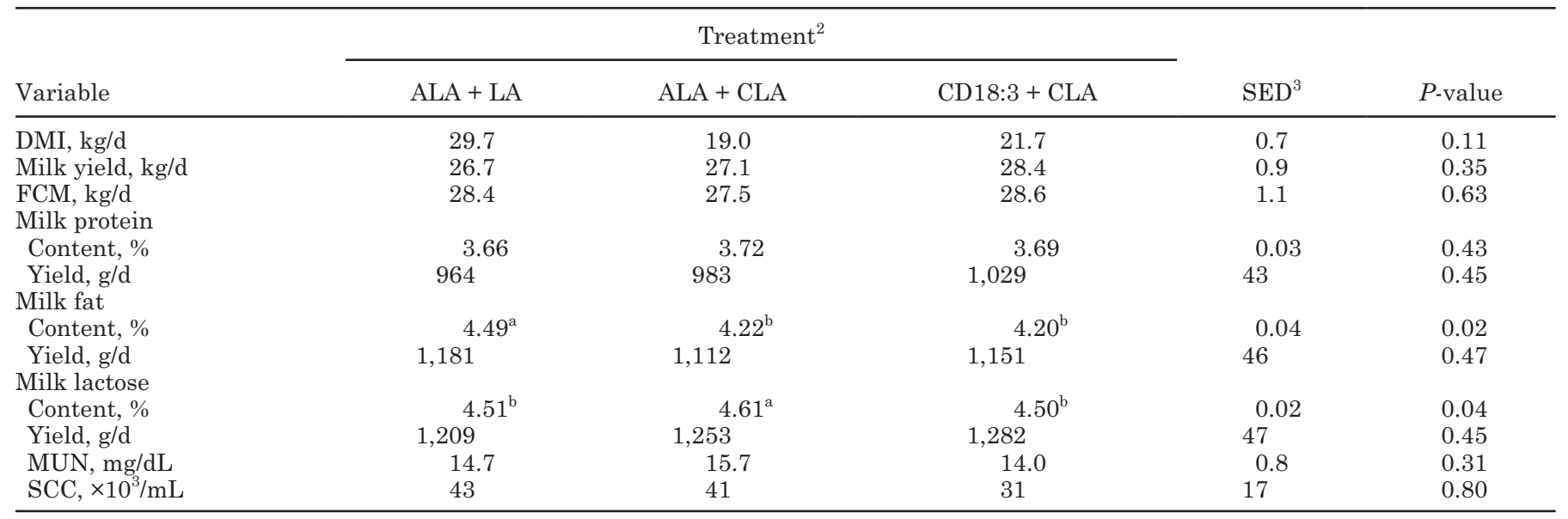

\footnotetext{
${ }^{\mathrm{a}, \mathrm{b}}$ Superscript letters within a row denote differences $(P<0.05)$.

${ }^{1}$ Values represent means from $\mathrm{d} 4$ and 5 of infusion of fatty acid supplements for 3 cows.

${ }^{2}$ See Table 3 for composition.

${ }^{3} \mathrm{SED}=$ standard error of the least squares means difference.
} 
acid in the rumen. Intravenous infusion was used as a simple experimental procedure to ensure complete protection of fatty acid supplements from rumen biohydrogenation (Viswanadha et al., 2003). The CD18:3 + CLA treatment group received an intravenous infusion of $5 \mathrm{~g}$ of each isomer of CD18:3 daily to ensure that the effect of these isomers on milk fat synthesis could be compared with those from other biohydrogenation intermediates studied in published experiments (Peterson et al., 2002; Perfield et al., 2004, 2007; Sæbø et al., 2005a,b).

Dry matter intake and BW were not affected by intravenous infusion of the fatty acid supplements (Table 4). Milk yield and protein were not altered by treatment. In contrast, over the experimental period, milk fat content was decreased by $7 \%$ for cows that received ALA + CLA and CD18:3 + CLA compared with ALA + LA. The temporal pattern of milk fat content showed a linear decrease during the infusion period for ALA + CLA and CD18:3 + CLA treatment groups (Figure 1). At the end of the period, return to preinfusion milk fat content was observed for all treatments (Figure 1).

The decrease in milk fat content was similar for ALA + CLA and CD18:3 + CLA treatment groups (Table 4). Results from previous studies established a strong negative relationship between milk fat synthesis and concentration of trans-10, cis-12 18:2 in milk fat (Peterson et al., 2002; de Veth et al., 2004). The extent of decline in milk fat content observed in the current study was consistent with what would be predicted based on the increase in milk fat concentration of trans-10, cis12 18:2 for ALA + CLA and CD18:3 + CLA treatment groups (Table 5). However, the reduction in milk fat content observed for these 2 treatment groups was not associated to a decrease in milk fat yield, as opposed to results from many other studies investigating the effects of trans-10, cis-12 18:2 on milk fat synthesis in dairy cows (Kay et al., 2007; Baumgard et al., 2000, 2001). In the current study, ALA + CLA and CD18:3 + CLA treatments both provided $1.3 \mathrm{~g} / \mathrm{d}$ of trans-10, cis-12 18:2. This low dose of trans-10, cis-12 18:2 might explain the lack of effect on milk fat yield.

Viswanadha et al. (2003) observed a linear decrease with increasing doses of intravenously infused trans-10, cis-12 18:2 up to $6 \mathrm{~g} / \mathrm{d}$. Therefore, the daily amount of trans-10, cis-12 18:2 used in the present work was below the dose that would induce a maximum level of MFD, allowing the expression of any additive effect of other fatty acids on milk fat synthesis.

The CD18:3 + CLA treatment provided $5 \mathrm{~g}$ of each CD18:3 isomer daily. Bauman et al. (2008) established that, when abomasally infused, the median effective dose of trans-10, cis-12 18:2 was $2.5 \mathrm{~g} / \mathrm{d}$ and corresponded to a $25 \%$ reduction in milk fat yield. Intra- venous administration of trans-10, cis-12 18:2 affects milk fat synthesis as efficiently as abomasal infusion (Viswanadha et al., 2003). Consequently, the daily supply of CD18:3 isomers was calculated to allow an effect on milk fat yield if these isomers had to be considered as inhibitors of milk fat synthesis at a dose comparable to trans-10, cis-12 18:2.

Variations in fatty acid content of treatments resulted in differences in fatty acid composition of milk for the respective isomers infused, except for cis-9, trans-11 18:2, which showed a similar content in milk fat for all treatment groups (Table 5; Figure 2). Under the conditions used in this experiment, cis-9, trans-13, cis-15 18:3 was not detectable in milk fat, unless CD18:3 + CLA supplement was provided (Figure 3). Therefore, no statistical analysis was performed on this specific isomer. The transfer efficiency of trans-10, cis-12 18:2 into milk fat when cows received either ALA + CLA or CD18:3 + CLA treatments was 16\% (Figure 4). This value is comparable to the average of $22 \%$ estimated by de Veth et al. (2004) from a summary of published studies in which cows received abomasal infusion of trans-10, cis-12 18:2. In contrast, the efficiency of transfer of trans-10, cis-12 18:2 observed in the present trial was much greater than the one calculated from data published by Viswanadha et al. $(2003 ;<2 \%)$ when lactating dairy cows were intravenously infused 2 to 6 $\mathrm{g} / \mathrm{d}$ of trans-10, cis-12 18:2. The greater transfer efficiency of trans-10, cis-12 18:2 might be explained by the fact that, in contrast to Viswanadha et al. (2003), the supplements were continuously infused in the jugular

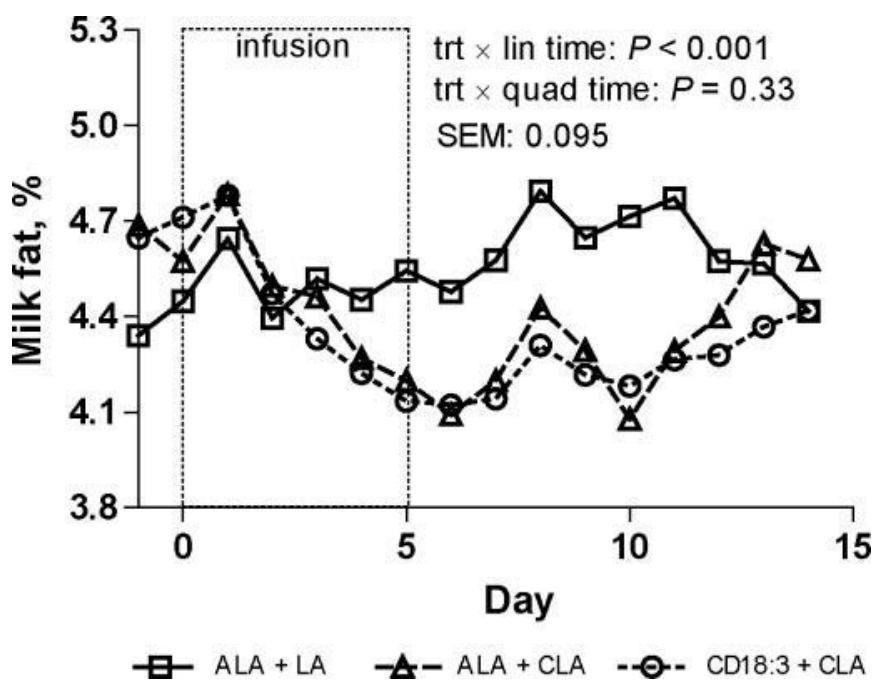

Figure 1. Temporal pattern of milk fat content in lactating cows during intravenous infusion of ALA + LA, ALA + CLA, or CD18:3 + CLA; see Table 3 for composition; $\mathrm{n}=3$. $P$-values represent the interaction between treatment and linear (lin) and quadratic (quad) effects of time during the infusion (from d 0 to $d 5$ ). 
Table 5. Fatty acid composition of milk fat from lactating cows during intravenous infusion of fatty acid supplements ${ }^{1}$

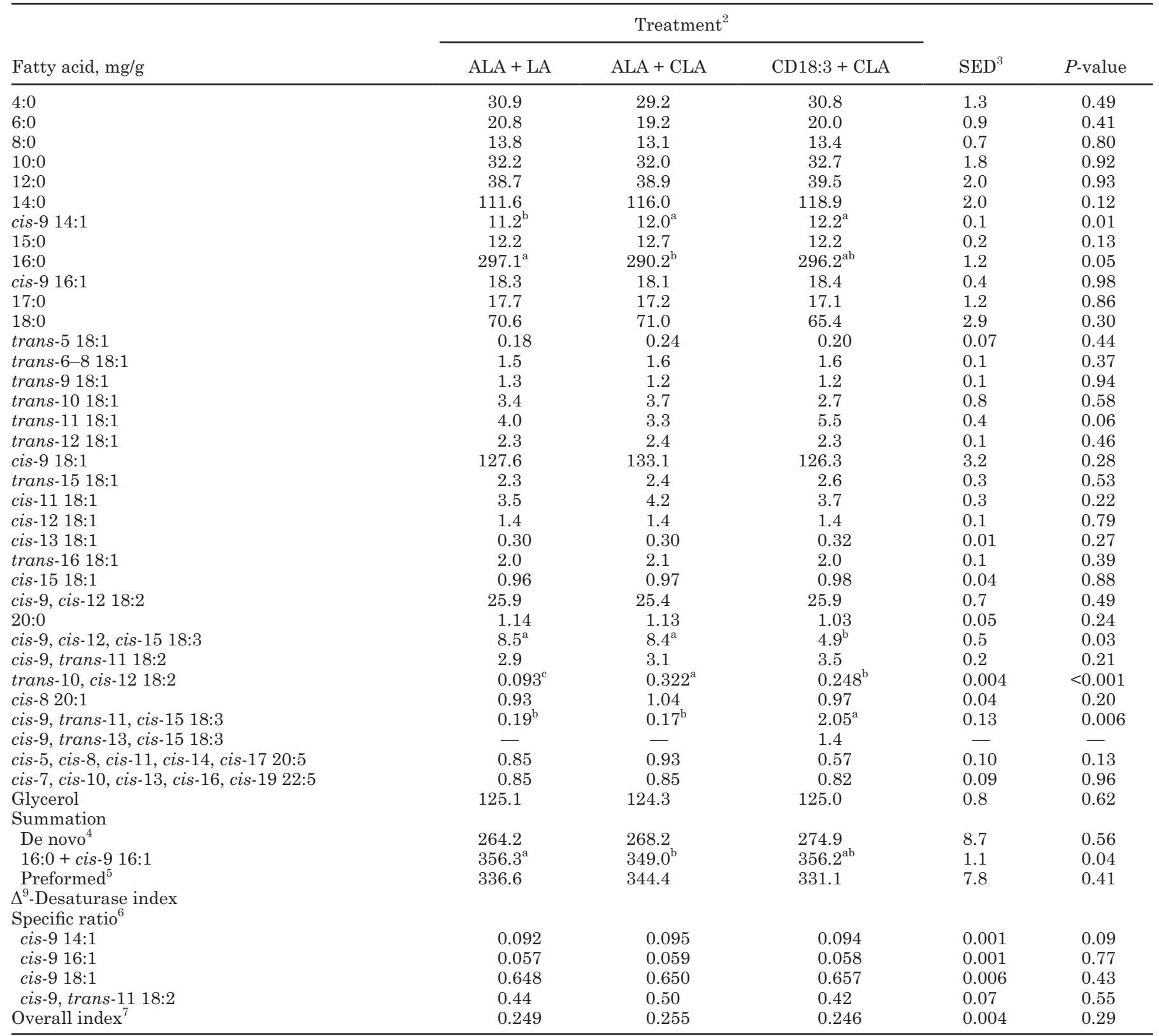

${ }^{a-c}$ Superscript letters within a row denote differences $(P<0.05)$.

${ }^{1}$ Values represent means from $d 4$ and 5 of infusion of fatty acid supplements for 3 cows.

${ }^{2}$ See Table 2 for composition.

${ }^{3} \mathrm{SED}=$ standard error of the least squares means difference.

${ }^{4}$ Fatty acids with chain lengths from 6 to 14 .

${ }^{5}$ Fatty acids with chain lengths of 15,17 , or longer.

${ }^{6}$ Specific ratios for $\Delta^{9}$-desaturase activity are ratio of the $\Delta^{9}$-desaturase product divided by the sum of the $\Delta^{9}$-desaturase product and substrate as described by Kelsey et al. (2003): cis-9 14:1 = (cis-9 14:1)/(cis-9 14:1 + 14:0); cis-9 16:1 = (cis-9 16:1)/(cis-9 16:1 + 16:0); cis-9 18:1 = (cis-9 18:1)/(cis-9 18:1 + 18:0); cis-9, trans-11 18:2 = (cis-9, trans-11 18:2)/(cis-9, trans-11 18:2 + trans-11 18:1).

${ }^{7}$ Overall $\Delta^{9}$-desaturase index was calculated as follows: $[($ cis-9 14:1) $+($ cis-9 16:1 $)+($ cis-9 18:1) $+($ cis-9, trans-11 18:2)]/[(cis-9 14:1 + 14:0) + $($ cis-9 16:1 + 16:0) + (cis-9 18:1 + 18:0) + (cis-9, trans-11 18:2 + trans-11 18:1)].

vein of the cows. Another explanation may be related to the differences between the emulsion processes used in the 2 studies. In the work from Viswanadha et al.
(2003), the fatty acid supplements were obtained via sonication of the mixtures, as opposed to the present trial, in which the emulsion was achieved using a high- 
$c-9, c-12, c-15$ 18:3

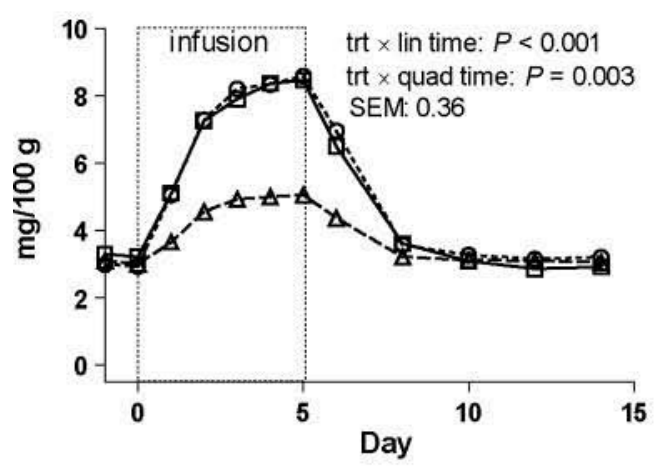

$c-9, t-13, c-1518: 3$

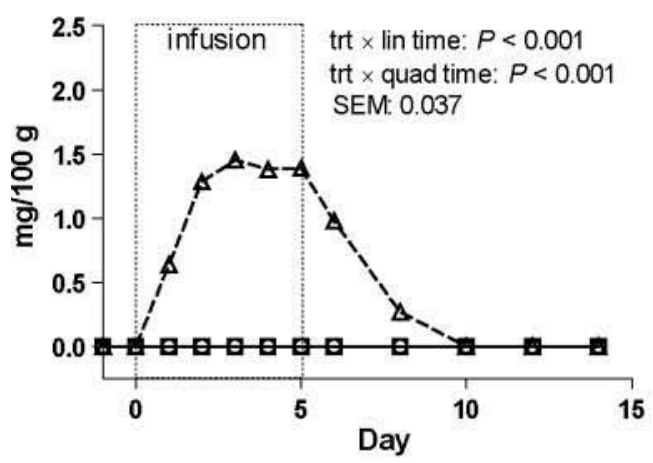

$c-9, t-11, c-1518: 3$

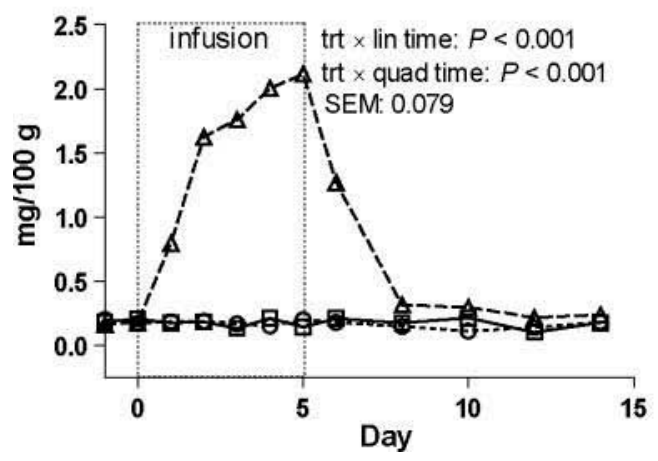

$c-9, c-12$ 18:2

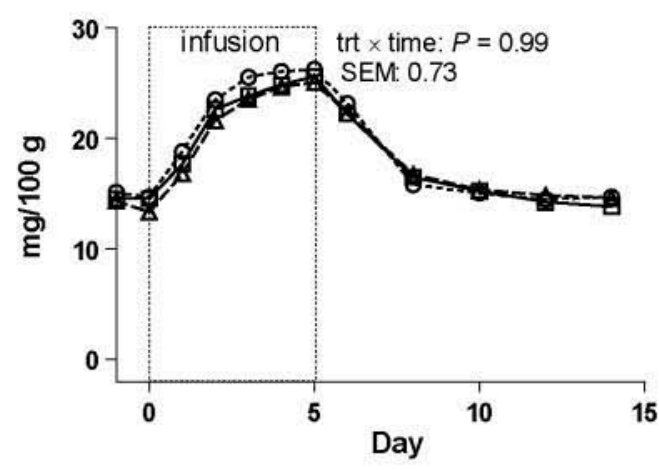

$t-10, c-1218: 2$

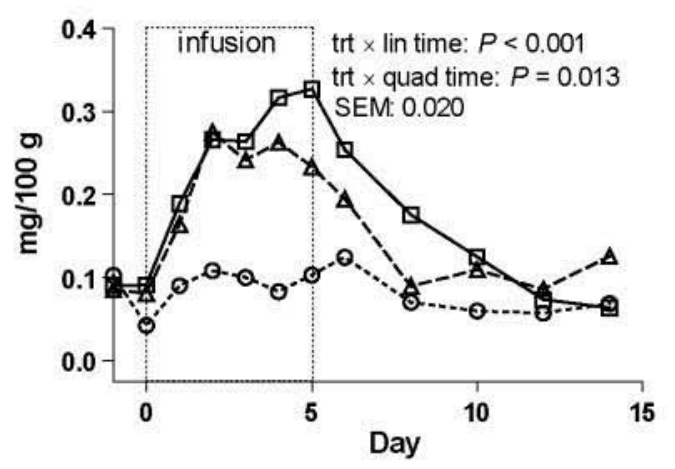

-๑-- ALA + LA ॄ-ALA + CLA -A- CD18:3 + CLA

Figure 2. Temporal pattern of selected milk fatty acids from lactating cows during intravenous infusion of ALA + LA, ALA + CLA, or CD18:3 + CLA; see Table 3 for composition; $n=3 . P$-values represent the interaction between treatment and linear (lin) and quadratic (quad) effects of time during the infusion (from d 0 to $d 5$ ).

pressure homogenizer. Transfer efficiencies of CD18:3 isomers averaged 39 and $32 \%$ for cis-9, trans-11, cis- 15 18:3 and cis-9, trans-13, cis-15 18:3, respectively. These observations are consistent with those of Sæbø et al. (2005a), who reported a greater numerical value for transfer efficiency of different CD18:3 isomers when compared with trans-10, cis-12 18:2.

Isomers of CD18:3 were taken up from blood by the mammary gland and incorporated into milk fat. However, the uptake of these isomers did not result in any additional effect on milk fat synthesis when compared with positive control (ALA + CLA). Therefore, the decrease in milk fat content observed in the CD18:3+ CLA treatment group is due solely to the presence of trans-10, cis-12 18:2 in the supplement.

Chouinard et al. (1999) reported that dietary supplements of CLA altered de novo fatty acid synthesis in lactating dairy cows. However, Baumgard et al. (2002) demonstrated that decrease in expression of lipoprotein lipase and fatty acid binding protein, 2 key enzymes in 

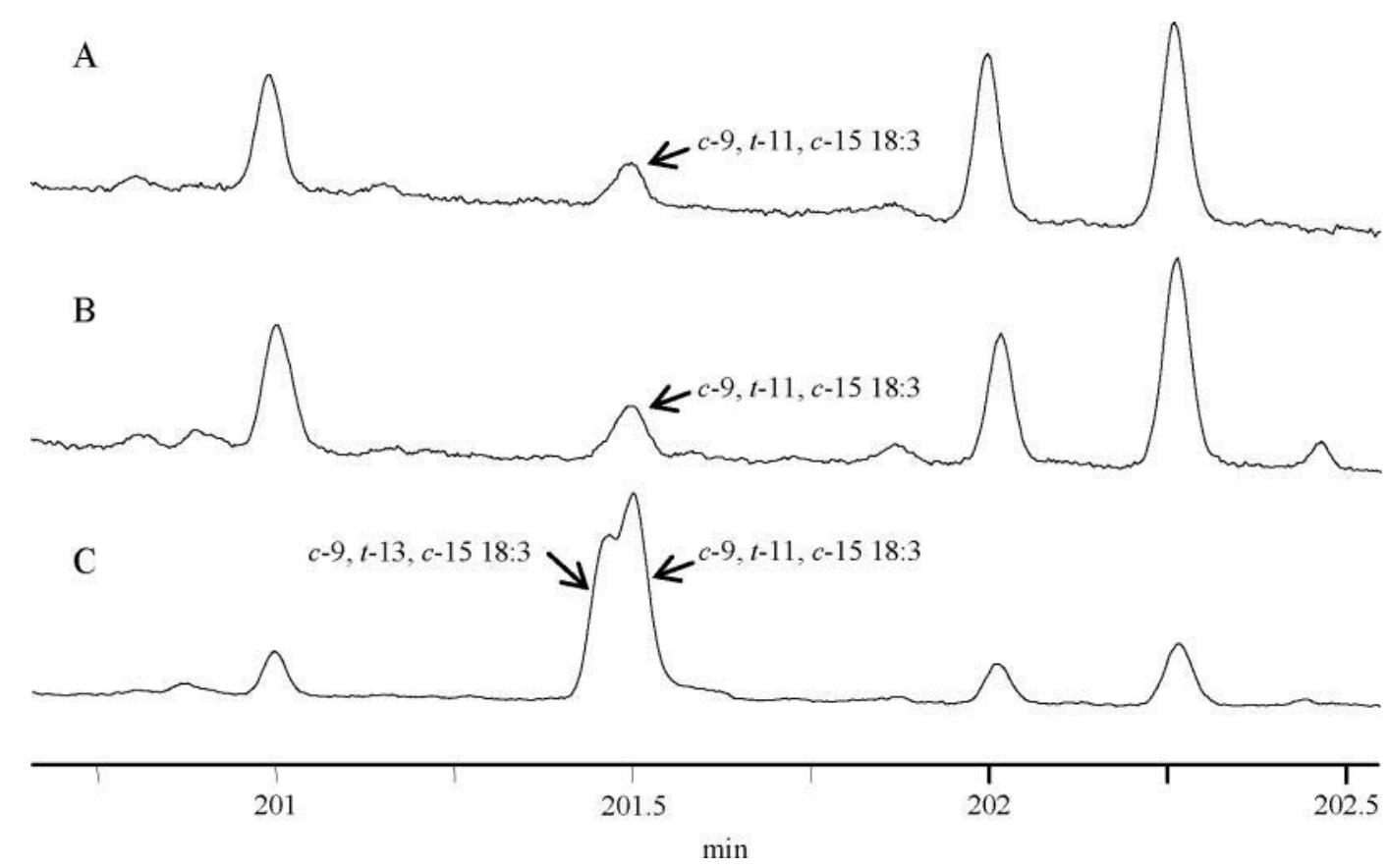

Figure 3. Partial gas chromatograms of milk fat from cows after 5 d of intravenous infusion of ALA + LA (A), ALA + CLA (B), CD18:3 + CLA (C); see Table 3 for composition.

the use of preformed fatty acids for milk fat synthesis, occurred when cows received trans-10, cis-12 18:2. Consistent with these observations, many other studies reported reduction in the yields of most fatty acids, with effects primarily on de novo fatty acids when cows received high doses of abomasally or intravenously infused trans-10, cis-12 18:2 (Baumgard et al., 2000; Perfield et al., 2002). Nevertheless, results from trials in which lower doses of trans-10, cis-12 18:2 were provided to dairy cows, as in the current study, showed a reduction in milk fat yield more equally distributed among fatty acids (Baumgard et al., 2001; Peterson et al., 2002). This could explain the lack of effect of treatment on milk fat composition of short-, medium-, and long-chain fatty acids observed in the present experiment (Table 5).

Another effect of trans-10, cis-12 18:2 that has been observed in lactating dairy cows is its ability to alter the fatty acid composition of milk by reducing the product:substrate ratios related to $\Delta^{9}$-desaturase (Chouinard et al., 1999). Baumgard et al. (2002) demonstrated that abomasal infusion of trans-10, cis-12 18:2 decreased the mRNA abundance for $\Delta^{9}$-desaturase in the mammary gland of dairy cows. However, many studies showed no effect on $\Delta^{9}$-desaturase when cows received low doses of trans-10, cis-12 18:2 (Peterson et al., 2002; Sæbø et al., 2005a). As expected, based on the low dose of trans-10, cis-12 18:2 used in this study, no effect of treatment was observed on any of the product:substrate ratios related to the desaturase index (Table 5).

Serum concentrations of NEFA and triacylglycerol were not affected by treatments (Table 6). Previously, trans-10, cis-12 18:2 has been shown to increase plasma NEFA from 30 to $200 \%$ when intravenously infused to dairy cows at doses ranging from 2 to $6 \mathrm{~g} / \mathrm{d}$ (Viswanadha et al., 2003). Again, the smaller dose of trans-10, cis-12 18:2 $(1.3 \mathrm{~g} / \mathrm{d})$ used in the current study could explain the discrepancy. However, many other trials in which trans-10, cis-12 18:2 was provided into the abomasum at greater doses did not report changes in blood concentrations of NEFA (Perfield et al., 2002; CastañedaGutiérrez et al., 2007). In contrast with the study by Viswanadha et al. (2003), the supplements used in this experiment were isolipidic and continuously infused in the jugular vein of the cows. This might explain the variation between the 2 studies. Serum concentration of glucose tended to be greater for cows receiving the CD18:3 + CLA supplement (Table 2). Giguère et al. (2006) investigated the effects of CLA and a mixture of CD18:3 similar to the one used in the current study on glucose metabolism in the piglet. Their work provided evidence that both dietary CLA and CD18:3 influence glucose homeostasis but through different metabolism in the piglet. Previous studies demonstrated that trans-10, cis-12 18:2 did not alter blood glucose concentrations in dairy cows (Moore et al., 2004; Selberg et al., 2004). In contrast, Odens et al. (2007) observed a 
Table 6. Serum concentrations of glucose, triacylglycerol, and NEFA during intravenous infusion of fatty acid supplements ${ }^{1}$

\begin{tabular}{lccccc}
\hline & \multicolumn{5}{c}{ Treatment $^{2}$} \\
\cline { 2 - 4 } Variable & ALA + LA & ALA + CLA & CD18:3 + CLA & SED $^{3}$ & $P$-value \\
\hline Glucose, $\mathrm{mmol} / \mathrm{L}$ & 3.19 & 3.28 & 3.46 & 0.06 & 0.09 \\
Triacylglycerol, $\mu \mathrm{mol} / \mathrm{L}$ & 221 & 226 & 230 & 11 & 0.71 \\
NEFA, $\mu \mathrm{mol} / \mathrm{L}$ & 283 & 193 & 290 & 135 & 0.79 \\
\hline
\end{tabular}

${ }^{1}$ Values represent an average for serum collected at 0800 and $1700 \mathrm{~h}$ on $\mathrm{d} 4$ and 5 of infusion for 3 cows.

${ }^{2}$ See Table 3 for composition.

${ }^{3} \mathrm{SED}=$ standard error of the least squares means difference.

significant increase in blood glucose (11\%) when dairy cows were fed CLA supplements from $10 \mathrm{~d}$ precalving to $40 \mathrm{~d}$ postcalving at a dose of 174 or $58 \mathrm{~g} / \mathrm{d}$ (depending upon DIM). In the current study, the effects of treatment on milk lactose were not consistent with the effects on blood glucose, suggesting that the latter might be of questionable biological importance. Additional studies would be necessary for a better understanding of possible interactions between CLA or CD18:3 and glucose metabolism in lactating dairy cows.

In conclusion, the current study investigated the effect of intravenous infusion of 2 CD18:3 isomers, intermediates in the biohydrogenation of a-linolenic acid in the rumen, on milk fat synthesis in dairy cows. Isomers of CD18:3 were taken up from blood by the mammary gland and incorporated into milk fat with

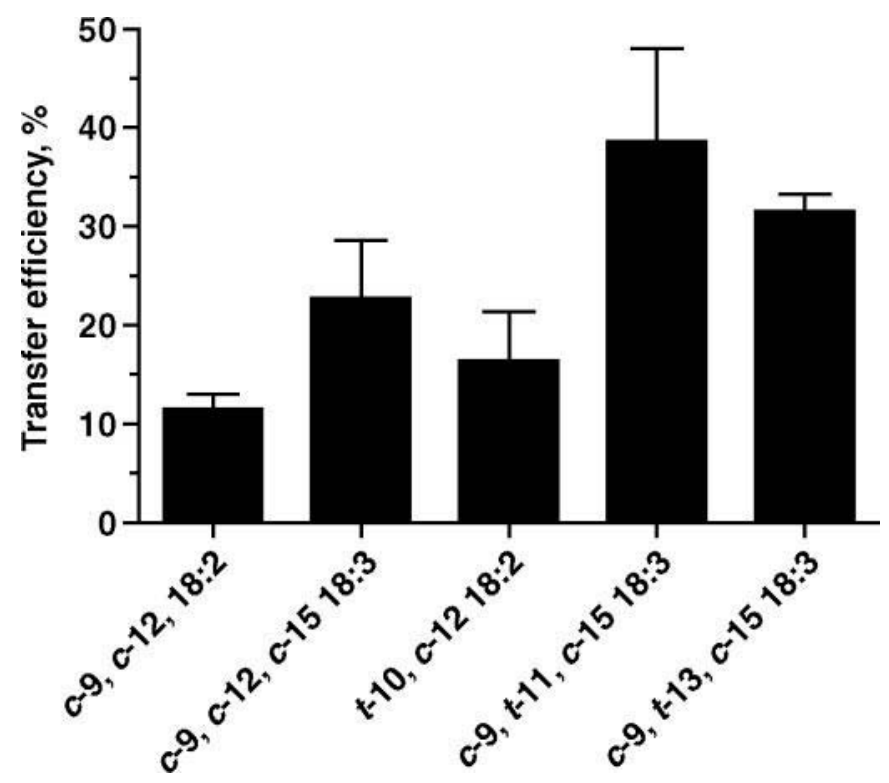

Figure 4. Apparent transfer efficiency of intravenously infused fatty acids into milk fat of dairy cows. Each column represents the mean $( \pm \mathrm{SD})$ for transfer, calculated on $\mathrm{d} 4$ and 5 of infusion of fatty acid supplements for 3 cows. $\mathrm{n}=9$ for cis-9, cis-12 18:2 and cis-9, cis-12, cis-15 18:3, $\mathrm{n}=6$ for trans-10, cis-12 18:2, and $\mathrm{n}=3$ for cis-9, trans-11, cis-15 18:3 and cis-9, trans-13, cis-15 18:3. transfer efficiencies of 39 and $32 \%$ for cis-9, trans- 11 , cis-15 18:3 and cis-9, trans-13, cis-15 18:3, respectively. However, the uptake of these isomers did not influence milk fat synthesis of the CD18:3 + CLA treatment group. The decreases in milk fat content observed in the CD18:3 + CLA and ALA + CLA treatment groups were similar and, therefore, attributable solely to the presence of trans-10, cis-12 18:2 in both supplements. These results offered no support for a role of either cis9, trans-11, cis-15 18:3 or cis-9, trans-13, cis-15 18:3 in MFD at a dose in which trans-10, cis-12 CLA is effective in reducing milk fat secretion.

\section{ACKNOWLEDGMENTS}

This project was supported in part by the Natural Sciences and Engineering Research Council (Ottawa, Ontario, Canada). Sincere appreciation is extended to Jean-Michel Garro and Naturia Inc. (Sherbrooke, Québec, Canada) for manufacture of the CD18:3 isomers. We also thank the administration and staff of the Centre de Recherche en Sciences Animales de Deschambault (Québec, Canada) for care and feeding of cows and especially Martin Tremblay for technical support. The assistance of the following students and colleagues at Université Laval in implementing the study is also gratefully acknowledged and appreciated: Édith Charbonneau, Mélanie Plourde, Audrey Doyon, Micheline Gingras, and Mélanie Martineau.

\section{REFERENCES}

Banni, S. 2002. Conjugated linoleic acid metabolism. Curr. Opin. Lipidol. 13:261-266.

Bauman, D. E., and J. M. Griinari. 2001. Regulation and nutritional manipulation of milk fat: Low-fat milk syndrome. Livest. Prod. Sci. 70:15-29.

Bauman, D. E., J. W. Perfield II, K. J. Harvatine, and L. H. Baumgard. 2008. Regulation of fat synthesis by conjugated linoleic acid: Lactation and the ruminant model. J. Nutr. 138:403-409.

Baumgard, L. H., B. A. Corl, D. A. Dwyer, A. Sæbø, and D. E. Bauman. 2000. Identification of the conjugated linoleic acid isomer that inhibits milk fat synthesis. Am. J. Physiol. Regul. Integr. Comp. Physiol. 278:R179-R184. 
Baumgard, L. H., E. Matitashvili, B. A. Corl, D. A. Dwyer, and D. E. Bauman. 2002. Trans-10, cis-12 conjugated linoleic acid decreases lipogenic rates and expression of genes involved in milk lipid synthesis in dairy cows. J. Dairy Sci. 85:2155-2163.

Baumgard, L. H., J. K. Sangster, and D. E. Bauman. 2001. Milk fat synthesis in dairy cows is progressively reduced by increasing supplemental amounts of trans-10, cis-12 conjugated linoleic acid (CLA). J. Nutr. 131:1764-1769.

Castañeda-Gutiérrez, E., B. C. Benefield, M. J. de Veth, N. R. Santos, R. O. Gilbert, W. R. Butler, and D. E. Bauman. 2007. Evaluation of the mechanism of action of conjugated linoleic acid isomers on reproduction in dairy cows. J. Dairy Sci. 90:4253-4264.

Chouinard, P. Y., L. Corneau, D. M. Barbano, L. E. Metzger, and D. E. Bauman. 1999. Conjugated linoleic acids alter milk fatty acid composition and inhibit milk fat secretion in dairy cows. J. Nutr. 129:1579-1584.

Chouinard, P. Y., J. Levesque, V. Girard, and G. J. Brisson. 1997. Dietary soybeans extruded at different temperatures: Milk composition and in situ fatty acid reactions. J. Dairy Sci. 80:2913-2924.

Davis, C. L., and R. E. Brown. 1970. Low-fat milk syndrome. Pages 545-564 in Digestion and Metabolism in the Ruminant. A. T. Phillipson, ed. Oriel Press, Newcastle upon Tyne, UK.

Destaillats, F., O. Berdeaux, J. L. Sebedio, P. Juaneda, S. Grégoire, J. M. Chardigny, L. Bretillon, and P. Angers. 2005a. Metabolites of conjugated isomers of a-linolenic acid (CLnA) in the rat. J. Agric. Food Chem. 53:1422-1427.

Destaillats, F., J. P. Trottier, J. M. G. Galvez, and P. Angers. 2005b. Analysis of a-linolenic acid biohydrogenation intermediates in milk fat with emphasis on conjugated linolenic acids. J. Dairy Sci. 88:3231-3239.

de Veth, M., J. Griinari, A.-M. Pfeiffer, and D. E. Bauman. 2004. Effect of CLA on milk fat synthesis in dairy cows: Comparison of inhibition by methyl esters and free fatty acids, and relationships among studies. Lipids 39:365-372.

Gervais, R., R. Spratt, M. Léonard, and P. Y. Chouinard. 2005. Lactation response of cows to different levels of ruminally inert conjugated linoleic acids under commercial conditions. Can. J. Anim. Sci. 85:231-242.

Giguère, A., S. Briand, J. J. Matte, and P. Angers. 2006. Conjugated linolenic acid (CLnA) and their role in the glucose metabolism in the piglet. Page 101 in 7th International Congress of International Society for the Study of Fatty Acids and Lipids, Queensland, Australia. Available online: http://www.issfal.org. uk/poster-session-b.html. Accessed March 2008.

Griinari, J. M., D. A. Dwyer, M. A. McGuire, D. E. Bauman, D. L. Palmquist, and K. V. V. Nurmela. 1998. Trans-octadecenoic acids and milk fat depression in lactating dairy cows. J. Dairy Sci. 81:1251-1261.

Kay, J. K., T. R. Mackle, D. E. Bauman, N. A. Thomson, and L. H. Baumgard. 2007. Effects of a supplement containing trans-10, cis12 conjugated linoleic acid on bioenergetic and milk production parameters in grazing dairy cows offered ad libitum or restricted pasture. J. Dairy Sci. 90:721-730.

Kepler, C. R., and S. B. Tove. 1967. Biohydrogenation of unsaturated fatty acids. III. Purification and properties of a linoleate $\Delta^{12}$. cis, $\Delta^{11}$-trans-isomerase from Butyrivibrio fibrisolvens. J. Biol. Chem. 242:5686-5692.

Kelsey, J. A., B. A. Corl, R. J. Collier, and D. E. Bauman. 2003 The effect of breed, parity, and stage of lactation on conjugated linoleic acid (CLA) in milk fat from dairy cows. J. Dairy Sci. 86:2588-2597.

Koba, K., A. Akahoshi, M. Yamasaki, K. Tanaka, K. Yamada, T. Iwata, T. Kamegai, K. Tsutsumi, and M. Sugano. 2002. Dietary conjugated linolenic acid in relation to CLA differently modifies body fat mass and serum and liver lipid levels in rats. Lipids 37:343-350.

Loor, J. J., A. Ferlay, A. Ollier, M. Doreau, and Y. Chilliard. 2005. Relationship among trans and conjugated fatty acids and bovine milk fat yield due to dietary concentrate and linseed oil. J. Dairy Sci. 88:726-740.
Moore, C. E., H. C. Hafliger III, O. B. Mendivil, S. R. Sanders, D E. Bauman, and L. H. Baumgard. 2004. Increasing amounts of conjugated linoleic acid (CLA) progressively reduces milk fat synthesis immediately postpartum. J. Dairy Sci. 87:18861895

NRC. 2001. Nutrient Requirements for Dairy Cattle. 7th rev. ed. Natl. Acad. Sci., Washington, DC

Odens, L. J., R. Burgos, M. Innocenti, M. J. VanBaale, and L. H. Baumgard. 2007. Effects of varying doses of supplemental conjugated linoleic acid on production and energetic variables during the transition period. J. Dairy Sci. 90:293-305.

Perfield, J. W. II, G. Bernal-Santos, T. R. Overton, and D. E. Bauman. 2002. Effects of dietary supplementation of rumen-protected conjugated linoleic acid in dairy cows during established lactation. J. Dairy Sci. 85:2609-2617.

Perfield, J. W. II, A. L. Lock, J. M. Griinari, A. Sæbø, P. Delmonte, D. A. Dwyer, and D. E. Bauman. 2007. Trans-9, cis-11 conjugated linoleic acid reduces milk fat synthesis in lactating dairy cows. J. Dairy Sci. 90:2211-2218.

Perfield, J. W. II, A. Sæbø, and D. E. Bauman. 2004. Use of conjugated linoleic acid (CLA) enrichments to examine the effects of trans-8, cis-10 CLA, and cis-11, trans-13 CLA on milk-fat synthesis. J. Dairy Sci. 87:1196-1202.

Peterson, D. G., L. H. Baumgard, and D. E. Bauman. 2002. Short communication: Milk fat response to low doses of trans-10, cis-12 conjugated linoleic acid (CLA). J. Dairy Sci. 85:1764-1766.

Peterson, D. G., E. A. Matitashvili, and D. E. Bauman. 2003. Dietinduced milk fat depression in dairy cows results in increased trans-10, cis-12 CLA in milk fat and coordinate suppression of mRNA abundance for mammary enzymes involved in milk fat synthesis. J. Nutr. 133:3098-3102.

Piperova, L. S., U. Moallem, B. B. Teter, J. Sampugna, M. P. Yurawecz, K. M. Morehouse, D. Luchini, and R. A. Erdman. 2004. Changes in milk fat in response to dietary supplementation with calcium salts of trans-18:1 or conjugated linoleic fatty acids in lactating dairy cows. J. Dairy Sci. 87:3836-3844.

Plourde, M., F. Destaillats, P. Y. Chouinard, and P. Angers. 2007. Conjugated a-linolenic acid isomers in bovine milk and muscle. J. Dairy Sci. 90:5269-5275.

Plourde, M., J.-P. Sergiel, J.-M. Chardigny, S. Grégoire, P. Angers, and J.-L. Sebedio. 2006. Absorption and metabolism of conjugated a-linolenic acid given as free fatty acids or triacylglycerols in rats. Nutr. Metab. 3:8.

Precht, D., J. Molkentin, M. A. McGuire, M. K. McGuire, and R. G. Jensen. 2001. Overestimates of oleic and linoleic acid contents in materials containing trans fatty acids and analyzed with short packed gas chromatographic columns. Lipids 36:213-216.

Sæbø, A., J. W. Perfield II, P. Delmonte, M. P. Yurawecz, P. Lawrence, J. T. Brenna, and D. E. Bauman. 2005a. Milk fat synthesis is unaffected by abomasal infusion of the conjugated diene 18:3 isomers cis-6, trans-10, cis-12 and cis-6, trans-8, cis-12. Lipids 40:89-95.

Sæbø, A., P. C. Sæbø, J. M. Griinari, and K. J. Shingfield. 2005b. Effect of abomasal infusions of geometric isomers of 10,12 conjugated linoleic acid on milk fat synthesis in dairy cows. Lipids 40:823-832.

Selberg, K. T., A. C. Lowe, C. R. Staples, N. D. Luchini, and L. Badinga. 2004. Production and metabolic responses of periparturient Holstein cows to dietary conjugated linoleic acid and trans-octadecenoic acids. J. Dairy Sci. 87:158-168.

Shingfield, K. J., and J. M. Griinari. 2007. Role of biohydrogenation intermediates in milk fat depression. Eur. J. Lipid Sci. Technol. 109:799-816.

Sutton, J. D. 1989. Altering milk composition by feeding. J. Dairy Sci. 72:2801-2814.

Viswanadha, S., J. G. Giesy, T. W. Hanson, and M. A. McGuire. 2003. Dose response of milk fat to intravenous administration of the trans-10, cis-12 isomer of conjugated linoleic acid. J. Dairy Sci. 86:3229-3236. 